\section{序章 初めに}

\section{(1) 本稿の背景と課題}

阪和商店街は戦後の闇市を起源とした商店街である。闇 市が各地に現れ始めたのは戦後すぐのことである．闇市は その違法性とは裏腹に, 国民の生活を支え, 1946年春頃 から全盛期を迎える．ただ，闇市を起源とする商店街は多 くが仮説的な建物であったため記憶に残りにくいという特 性がある.

これまでの研究では東京の 23 区内における，ヤミ市由 来の戦後のマーケットに関する研究が主になっており，そ れ以外の道府県を対象とした研究は数少ない. 東京を対象 とした先行研究には，松平誠による一連の闇市研究 ${ }^{1)}$ が ある. 松平は, マーケットは 1946 年春ごろに各地で現れ 始め, 1950 年ごろには主要なものは消滅していったと

し，戦後復興期特有の空間としてとらえている. 最近では 初田香成 (2003，2004） 2), 3), 石榑督和 (2013) 4) らの研 究が主にある. 初田の研究では, 戦後東京におけるバラッ ク飲み屋街がどのような経緯で形成され変容したのかを網 羅的に説いている. 都市計画という観点から 1950 年前後 と 1960 年代の二時期に分けて, 都市の中でバラック飲み 屋街が都市再開発とどのように結びついていたかを営業者 組織の記念誌から明らかにした。石榑の研究は, 新宿駅東 口を対象とし，対象地区を中心に新宿駅周辺の都市組織の 動態を，闇市を起源とするマーケットの発生と周辺への影 響に注目して明らかにした．どちらの研究もマーケットが 合法的な都市形成に大きく影響したとしている.

今回は対象を大阪・天王寺にある阪和商店街にし (図 1,2 の赤枠内), 阪和商店街がたどってきた変遷と, 商店 街の空間の変化を時系列て調查する．また，阪和商店街が なぜ，現在まで昭和の姿のまま残っているのかを明らかに する.

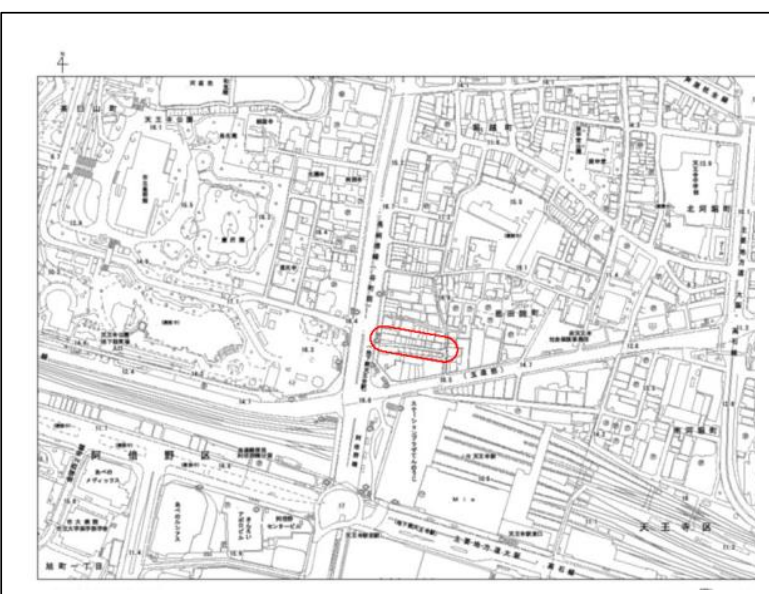

図 2: 天王寺区の地図 (出典: マップナビおおさか ${ }^{8)}$ )

\section{（2）阪和商店街について}

阪和商店街は図 1 に示寸通り，JR 天王寺駅の北口を出 て, 徒歩約 1 分の場所にある商店街である. 天王寺では近 年，阿倍野キューズモールや阿倍野ハルカスなどの開発事 業が活発に行われているが，その JR 天王寺駅周辺におい て阪和商店街は昭和の雾囲気を残している.

阪和商店街は戦争による焼け跡を不法占拠した闇市が起 源となっている. はじめは露店だったものが，次々にバラ ックになっていった. ただ，1955（昭和30）年7月 2 日

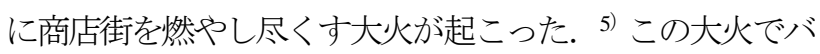
ラックは全焼し，土地だけ残った。 この時，土地の権利を 第三国人が買い取り，もともとここでバラックを建て，店 を開いていた 30 近くの営業者が土地を分譲してもらい,

阪和菓子市場を作った. 建物は再建の際に鉄骨造の長屋形 式で立て直し，その当時の地割がそのままの形で残されて いる (図 2 参照)。現在では駄菓子屋は 1 件しか残ってお らず, 残りは飲み屋となり, 飲み屋街となっている.

ここで闇市発生からマーケット形成までの流れについて

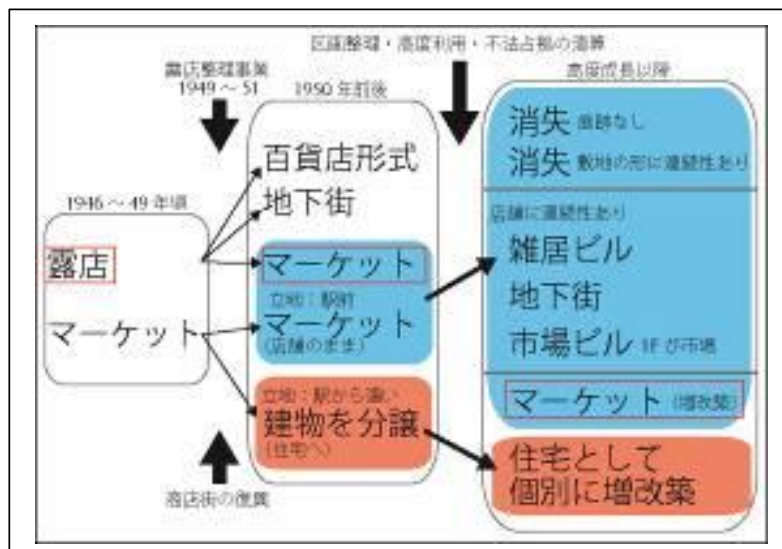

図 3 : 闇市形成からマーケット形成までの過程（参考: 石榑ら (2014) の研究)

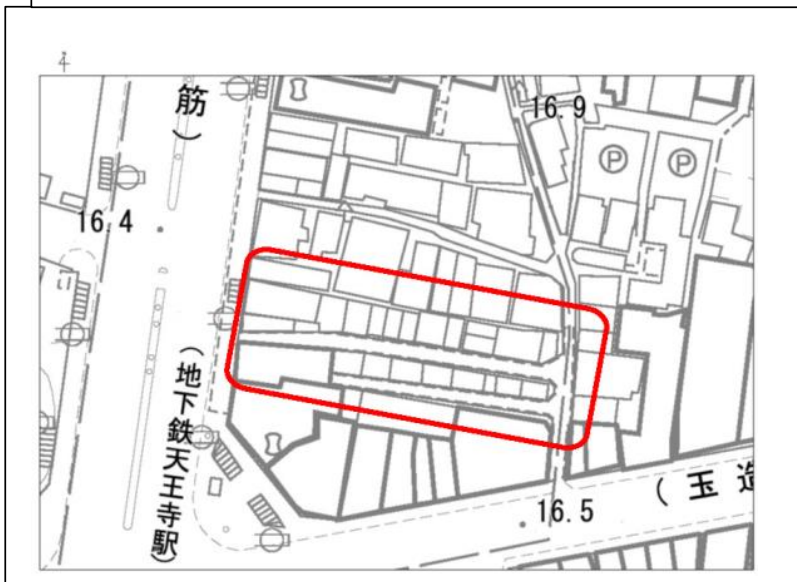

図 1 : 阪和商店街の地図 (出典: マップナビおおさか ${ }^{8)}$ ) 
図3 を用いてみてみる. 戦前からマーケットは存在してい た.しかし，戦後に残っていたのはごくわずかであった. また，露店は戦後特有のもので，闇市の代名詞ともいえ る. 図 3 の左の露占とマーケットは共に闇市を形作ったも のであるが，その歴史に多少の誤差がある. その後闇市で 商売をしていた店舗は生き残るために様々な変化を遂げ た.ただ，そのほとんどが，国の安定と共に，法整備が進 む中で消滅したり，百貨店形式になったり，土地区画整理 と共に地下に潜り込んだ.

阪和商店街は図 3 の赤枠で囲った形態に変化し，今もマ 一ケットだったころの姿を残している商店街である.

\section{口 本論 阪和商店街の位置づけと特徴 \\ (1) マーケットの類型}

ここでは石榑ら（2014）の研究6）をもとに阪和商店街 のヤミ市における平面計画を明らかにしていく。まずは石 榑らが表した類型を示す。それに，阪和商店街がどのよう に当てはまるのかを示す.

石榑ら（2014）は「（前述）ヤミ市の開発主体の介人方 法の違いを示していると考えられ，二つの累計が想定され よう。つまり，長屋形式のものは開発主体が一体的な開発 意図を持って建設し，商店主はその後に店舗を利用してい ると思われるのに対し，大きさの異なる戸建て形式のもの は，開発主体は土地を地割りしただけ，あるいは開発主体 が不在である場合で，それぞれの商店主が個別に建物を建 てていると思われる，ここでは前者を一体開発型，後者を 戸建て型と名付ける.」（p.2590） と定義されている. 阪 和商店街は長屋形式の商店街であるので，ここでは一体開 発型にの文触れる.

まずは敷地の接道する道路の数から図 4 の 5 つに大別さ れる. それぞれ 1 から順に数字の数だけ敷地と接道が接し

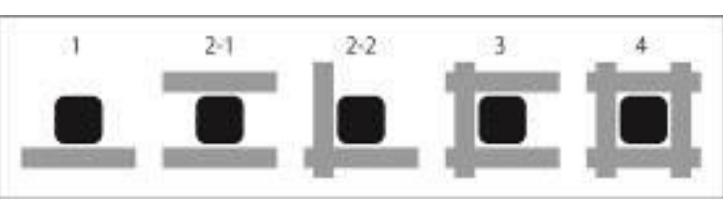

図 4 : 敷地の接道条件 (参考: 石榑らの研究 (2014))

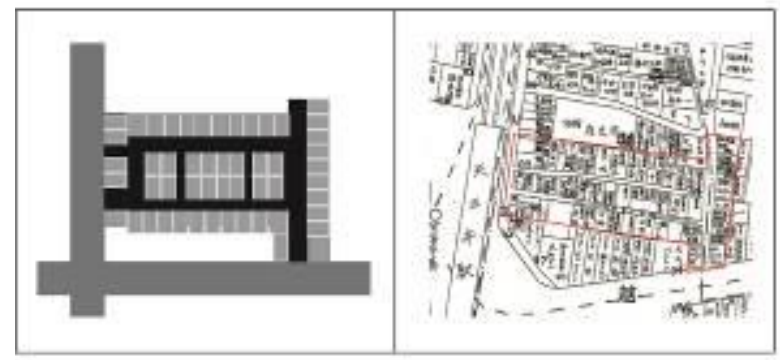

図 5(左) : 阪和商店街の平面配置のモデル（参考 : 石榑らの研 究 (2014))

図 6(右) : 阪和商店街の平面配置（出典 : 複製吉田地図 1970 (昭和 45) 年版)
ている.ただし，2だけ敷地の両端で接道しているものを 2-1，連続した 2 辺の道路に接道しているものを 2-2 とす る. さらに石榑ら（2014）は「この接道条件に加え，(1) 敷地の長辺方向，(2)敷地の短辺寸法，(3)周辺のコントラ ストといら三つの要件からマーケットの平面計画を説明す ることができる。接道条件「1」「2-1」の2つでは(1), (2)の要件から，また，接道条件「2-2」，「3」については (1)，(2)に加え(3)を検討することで平面の説明が可能であ る.」(p.2592) としている.

マーケットの配置は(1)の要件によって概ね決定され

る. マーケット内をめぐる主要な通路は，敷地の長手方向 に貫かれ，適宜短手方向で周囲の道路とネットワーク化 し，店舗は通路に向かって開いて配置されることになる. つまり，基本的には敷地の長辺方向に向かって通路が通さ れ，その通路に向かって店舗を開く形で配置される.

(2)の短辺の寸法は，マーケットを貫く通路の本数と, その通路に並ぶ店の数を決定付ける要件になる.

以上の 2 つの要件は敷地に対して効率的に通路を引き込 み, さらに，通路に対して効率的に店舗を配置するための 平面計画である. それに対して(3)の要件は，周辺を含め た都市組織のなかでメインストリートになっている道路 や，駅に向かって店を並べることを優先している場合であ る.

図 5 から阪和商店街は「2-2」の接道条件であることが わかる，つまり，(1)，(2)，(3)の要件をもとに平面計画が 行われていることがわかる. 石榑ら（2014）は(1)，(2)と (3)は対の関係にあり, どちらかを優先し, 平面配置が決 定されていると述べている。 しかし，阪和商店街において は必ずしもそうではないと考える。

図6から見て取れるように，各店舗が通路の方を向き， 大通りに面した店舗は大通りに面して開いている。これだ と(3)の要件によって商店街の平面配置は行われているよ うに見える. 一方で，阪和商店街は谷町筋とは大通りに直 接接していたものの, 玉造筋とは短辺方向に通路を伸ば し，つながっている，これは，図4の「1」に近い性質も 持っていることが考えられる. そして，「1」の条件であ ると，(1)，(2)の要件が極めて強く影響する傾向にある. それを加味して考えると，阪和商店街は(1)，(2)の要件に 強く影響を受け配置され，(3)の要件である大通りに面し ている面だけ，道路に対して開く形をとった商店街である ことが類推される.

次に，商店街の店舗ごとの構成と計画を見ていく．石榑 ら（2014）の研究によると，店舗の業種形体は間口と奥行 の比から判断することが可能であるとしている. 基本的に は飲食店は間口よりも奥行が長い傾向にある。一方の小売 店は奥行よりも間口が長い傾向にある。これは，小売店は 商品をいかに多く見せるかが重要で，飲食店は，いかに客 を中に引き込むかが重要になるからであると考えられる.

では，阪和商店街の場合はどうなのか. 入手できた一番 古い地図が 1970 (昭和 45）年の地図（図 6）であるの 
で，この地図で考察していく，因多に，阪和会会長へのヒ アリングから商店街の建物は大火があった 1955 (昭和

30）年から現在まで建て替え等は行われていないことがわ かり，1970（昭和 45）年の地図でも，差があまりないと

考えられる. 先に述べた通り，阪和商店街はもともと阪和 菓子市場であった，そのため，一部の店舗は奥行より間口 の方が長くなっている店舗がある.ただ，ヒアリングの結 果から, 敷地の広さに対して店舗の数が多く, 駄菓子屋で あっても間口より奥行の方が長い店舗の方が多く，一つひ とつの店舗面積も周辺の商店街と比較すると狭いという. 通常は間口が狭く奥行が長い店で構成されたマーケット は飲食店街的性格が強く, 間口が広く奥行が狭い店で構成 されたマーケットは小売店街的性格が強くなる. しかし， 阪和商店街は菓子市場として開始しているが，敷地と出店 者数の関係から，間口が狭く奥行が長い店舗が多くでき， 効率的でない商店街の平面構造をしていたことが分かっ た. 現在ではその多くが飲み屋として残されているのは, 店舗の構成といら面からみると, 至極当然の結果といえる のかもしれない.

また，地図からも商店街の構成を追うことができる．図 7, 図 8 の赤くなっている部分は菓子屋である. 図7 から は阪和菓子市場が阪和商店街に変わった年代が窺える.こ れは1962（昭和 37）年の商店街振興組合法の施行に影響 を受けていると考えられる.この法律は商店街のメンバー が結成した組合に対して法人格を与えるというものであ

る. 図 8 は1980（昭和 55）年から 1983 (昭和 58）年の間 で，菓子屋が半分近くに減少している．この年代はコンビ 二が普及し始める年代 7) である.

\section{（2）阪和商店街の特殊性}

阪和商店街のすぐ南に玉造筋という，大阪市天王寺区の 天王寺駅前交差点から都島区の京橋駅付近までの全区間で JR 大阪環状線の内側を併走している幹線道路が通ってい る. この道路の天王寺駅前交差点から南河堀交差点間を都 島阿倍野線（悲田院）といい，1946 年 5 月 22 日に都市計 画道路（以下，都計道と略す）に計画決定されている．都 計道に指定された道路周辺は建築制限がかかり，計画決定 された道路の範囲内の敷地は建築確認の前に，「都市計画 法 53 条許可申請」が必要になり, 事業決定された道路の

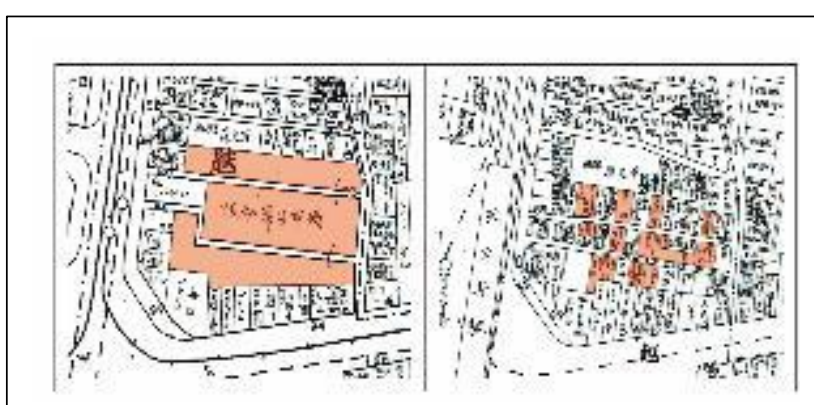

図 7 : 昭和 41 年と昭和 45 年の阪和商店街（出典 : 複製吉田地 困)
範囲内の敷地は原則として建築が認められなくなる.

さらに，阪和商店街周辺は一度も土地区画整理がされて いない場所であった. そのため, 土地が細分化し, さら に，無秩序に建物が建てられたことが窥える.

ただ，近年長期未着手の都計道の見直しが進められ，大 阪市も見直しに乗り出している. 2012 (平成 24）年の時 点で，大阪市では約 7 割が整備済み，約 1 割が事業中，残 りの 2 割が未着手の状態で残っていた. その未着手のう ち, 約 7 割が 50 年以上前に計画されたものであった.こ の，50 年以上未着手の者を長期未着手の都計道とし，見 直しの対象となった. その結果，2013（平成 25）年4月 に都島阿倍野線（悲田院）は廃止（図9）された。

また，用途地域をみると，阪和商店街を含む一角は商業 地域であるが，すぐ横の区画は住居系の地域になってい る. 周辺の住居系にある土地は区画整理をされた形跡もな く, 混沌とした状況になっている. そのためか, 図 10, 11 から読夕取れるように，周辺と比べて開発も少ない. 因夕に，図 10，11 の中心からみて北西の地区は天王動 物園や天王寺芝生公園がある場所である。この地区は 2015 (平成 27）年に芝生公園になったばかりで，大阪市 の事業の一部である.

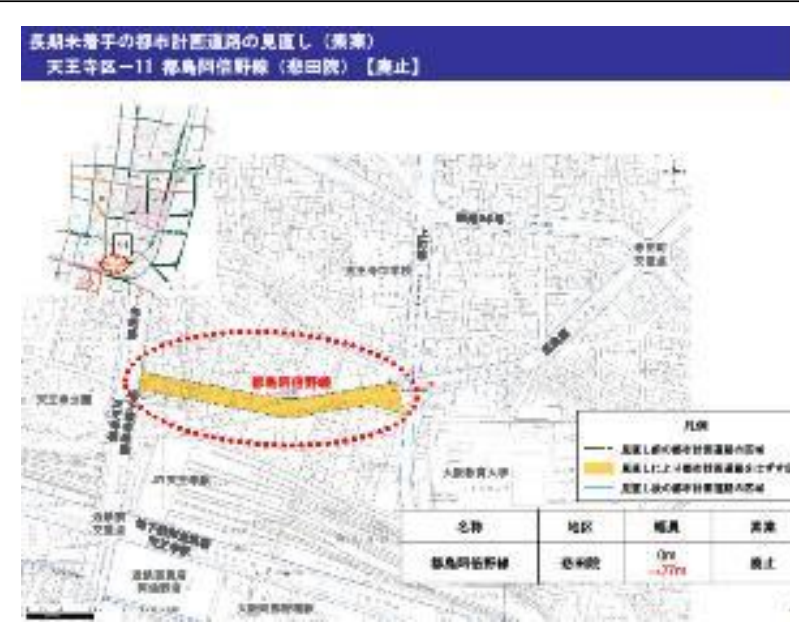

図 9 : 都市計画道路の都島阿倍野線（悲田院）（出典 : 大阪市天 王寺区 ${ }^{9)}$ )

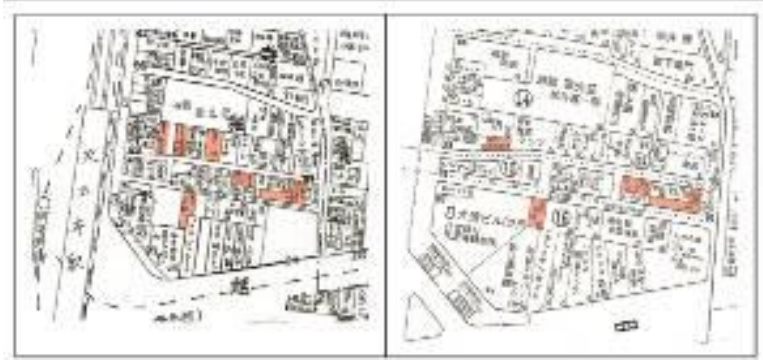

図 8 : 昭和 55 年と昭和 58 年の阪和商店街（出典 : 複製吉田地 四) 


\section{— 結論 阪和商店街がなぜ残ったのか}

以上のことからなぜ阪和商店街が現在まで昭和の雾囲 気を残しているのかを考察する．まず，阪和商店街の平 面計画と店舗の構成から考える. もともとは菓子市場と して始まったものの, 店舗の平面構成は小売店に向かな い間口が狭く奥行が長いものであった．また，立地も JR 天王寺駅の寸ぐ近くで，少し奥まったところにあったこ ともあり, どちらの要素においても飲み屋街としての要 素が強かった. 実際, 現在は飲み屋街として残ってい る.

次に，開発に対する周辺住民の反対があったことが考 えられる．用途地域にはあまり触れなかったが，阪和商 店街は商業用地になるが，すぐ北東の区画は大通りに面 したところ以外，住居系の用地で，大通りに面した商業 用地に囲まれる形で，住居系の用地が残っている. 最近 になって少しずつマンションが開発されるようになった が，住宅が無秩序に立ち並んでいる現状があり，開発が 進めにくいことが窥える.

最後に, 最近まで阪和商店街の南を通る都計道が計画 決定されていたことがあり，建築制限がかかっていたこ とが，開発されずにいた最大の要因だと考えられる．都 計道が計画決定された場所は，道路の整備と開発を同時 進行で行うのが基本的とされているため, 開発に乗り出 寸主体が現れなかったと考えられる.

この 3 つのことから，阪和商店街はその場所の特性を 生かしつつ，偶然にも，法的に開発から守られていたこ とが分かった.

これからの課題として，一番大きな要因であったと考 えられる都計道の計画決定の廃止が決まり，阪和商店街 の周辺も開発が始まる恐机があ. 開発することは悪い ことではないが，今日まで昭和の姿を残す阪和商店街の 趣を残すような開発の仕方が望まれ，求められる.

\section{口 参考文献}

1）松平誠，ヤミ市 幻のガイドブック，ちくま新書，1995 年7月 20 日 2）初田香成「戦後東京におけるバラック飲み屋街の形成と展開」日本建 築学会大会学術講演梗概集，p.467-468，2003 年9月

3）初田香成「戦後東京におけるバラック飲み屋街の形成と变容」日本建 築学会計画系論文集，第579 号, p.105-110，2004年 5 月

4）石榑督和，青井哲人「闇市の形成と土地所有からみる新宿東口駅前街 区の戦後復興過程 -新宿駅近傍における都市組織の動態をめぐってそ の1-」日本建築学会計画系論文集 第78 巻 第694 号, p.2627-2636, 2013 年 12 月

5）朝日新聞社，東京 夕刊，1955 年7月 3 日

6）石榑督和，初田香成「『新興市場地四』にみる戦後東京のマーケット の建築的分析」日本建築学会計画系論文集 第79巻 第705 号, p.25892597,2014 年 11 月

7）新雅史「商店街はなぜ烕びるのか 社会・政治・経済史から探る再生 の道」光文社新書, p.140-141, 2012 年

8）大阪市ホームページ http://www.city.osaka.lg.jp/ 2016年6月 27 日
9）大阪市 天王寺区ホームページ http://www.city.osaka.lg.jp/tennoji/ 2016年6月 27 日

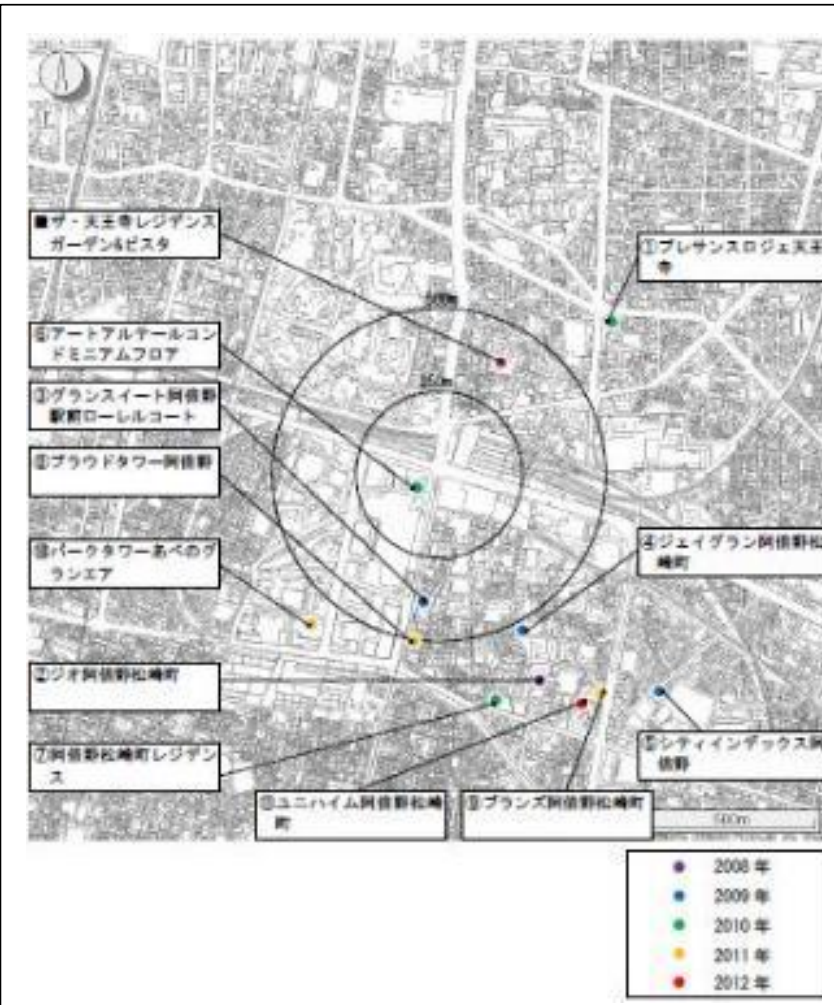

図 10 : 周辺のマンション開発の状況（出典 : 大阪市天王寺区 ${ }^{9)}$ )

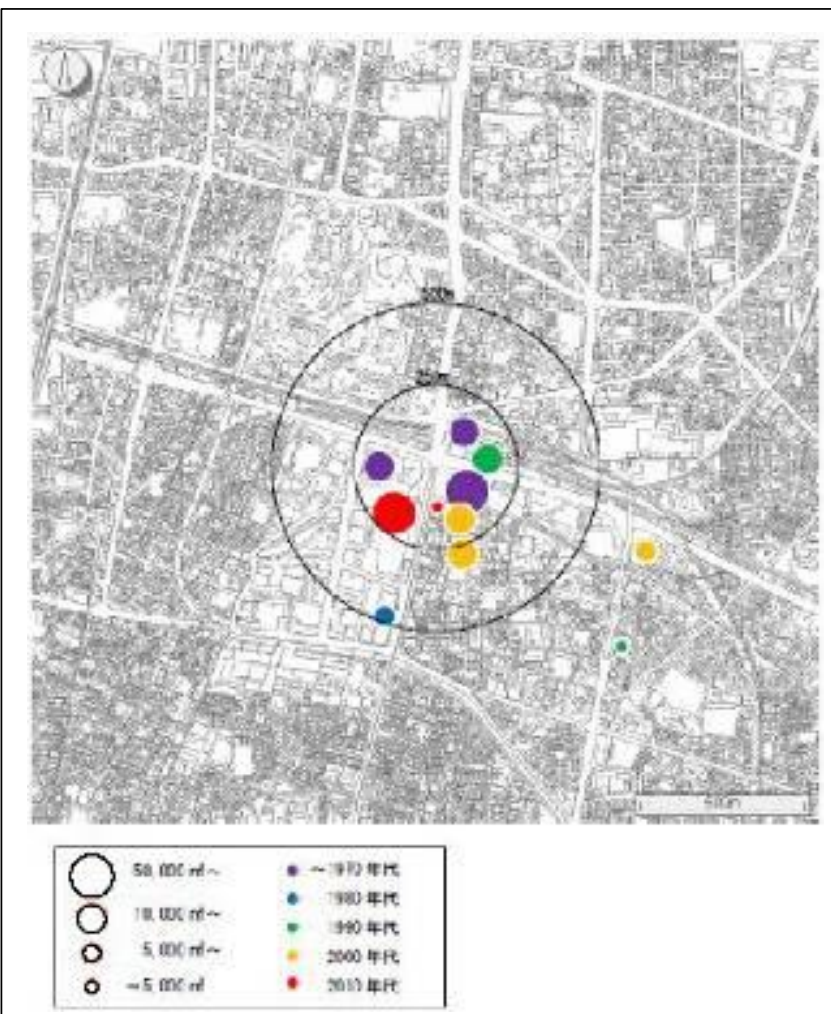

図 11 : 周辺の商業施設の状況（出典 : 大阪市天王寺区 ${ }^{9)}$ ) 